IMF Working Paper

C 1999 International Monetary Fund
This is a Working Paper and the author(s) would welcome any comments on the present text. Citations should refer to a Working Paper of the International Monetary Fund. The views expressed are those of the author(s) and do not necessarily represent those of the Fund.

WP/99/69

INTERNATIONAL MONETARY FUND

Monetary and Exchange Affairs

\title{
Economic and Legal Considerations of Optimal Privatization: Case Studies of Mortgage Firms (DePfa Group and Fannie Mae)
}

\author{
Hans-Joachim Beyer, Claudia Dziobek, and John R. Garrett ${ }^{1}$ \\ Authorized for distribution by William E. Alexander
}

May 1999

\begin{abstract}
Successful privatization must be accompanied by the complete removal of privileges and any public policy mission. Bank behavior changes rapidly as profit maximation replaces the bureaucratic objective function. Once privileges are granted, they are difficult to remove. Therefore, privatization is a one-time (nonreversible) operation. The German mortgage bank, DePfa, went through a carefully planned and lengthy privatization process that was successful. Fannie Mae, the U.S. mortgage firm, became a privately owned institution endowed with special privileges, which led to a quasi-monopoly position. This resulted in suboptimal financial sector performance. Fannie Mae's special privileges have proven resistant to reform efforts.
\end{abstract}

JEL Classification Numbers: G2; G38; L51

Keywords: Privatization, financial regulation, state banks, Fannie Mae, DePfa

Authors' E-Mail Addresses: Hans-Joachim_Beyer@voeb.de; Cdziobek@imf.org; John_Garrett@utc.edu

${ }^{1}$ Hans-Joachim Beyer, Association of Public Sector Banks, Bonn; Claudia Dziobek, IMF; John R. Garrett, University of Tennessee at Chattanooga. The paper has benefitted from discussions at the Federal Reserve Bank of Dallas and during the conference on Privatization of Banks co-sponsored by the Federal Reserve Bank of Dallas and the World Bank (March 1999). The authors would like to thank William E. Alexander, Stefan Ingves, Dwight Jaffee, and JoAnn Paulson for insightful comments. 


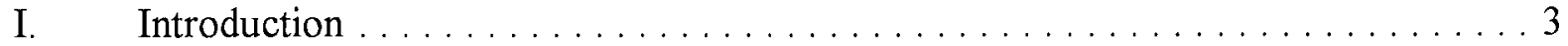

II. Policy Issues in Bank Privatization . . . . . . . . . . . . . . . . . 4

A. Special Purpose State Banks and Missing Markets $\ldots \ldots \ldots \ldots \ldots \ldots 4$

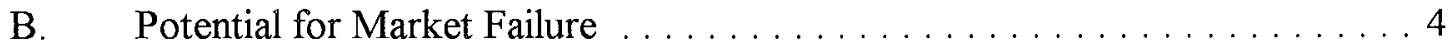

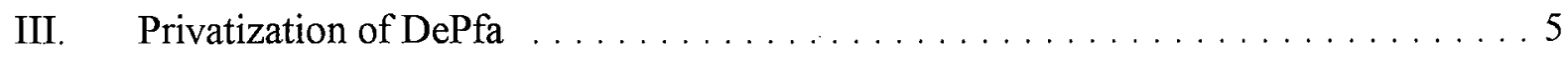

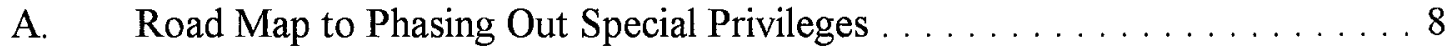

B. Economic Performance Since Privatization . . . . . . . . . . . . . 10

C. DePfa: Summary and Conclusions $\ldots \ldots \ldots \ldots \ldots \ldots \ldots$

IV. Privatization with Special Privileges of Fannie Mae . . . . . . . . . . . . . 14

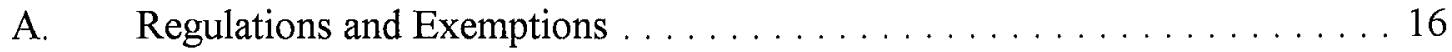

B. Monitoring of Fannie May by the Federal Government . . . . . . . . . 16

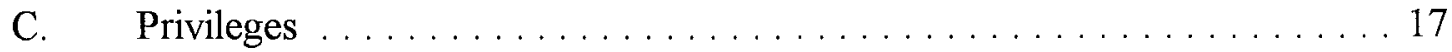

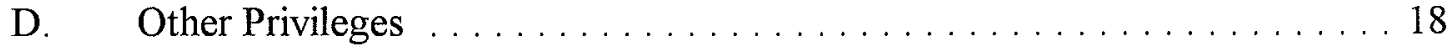

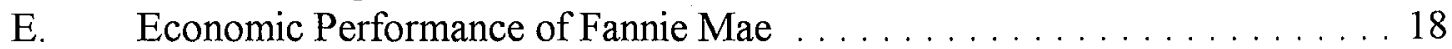

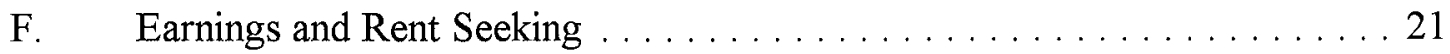

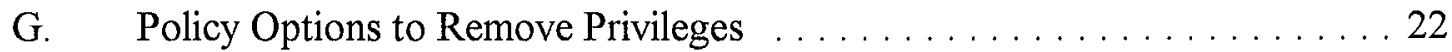

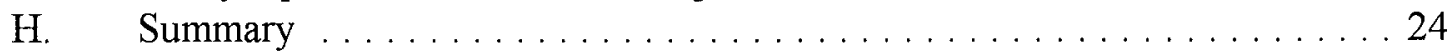

V. Conclusions and Lessons from DePfa and Fannie Mae ............... 24

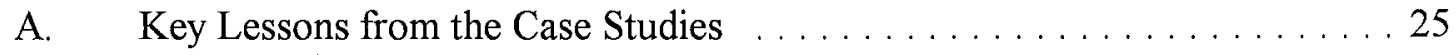

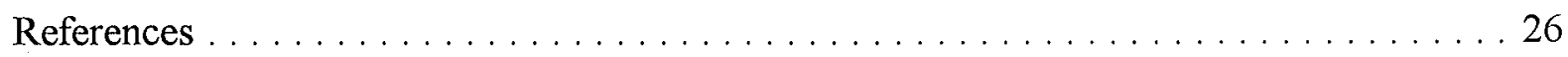

Text Boxes

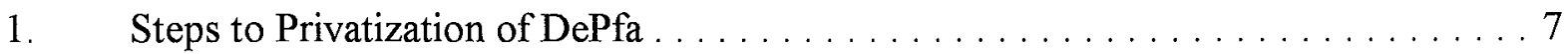

2. Fannie Mae: Privatization with Special Privileges $\ldots \ldots \ldots \ldots \ldots \ldots$

\section{Text Charts}

1. DePfa Bank Shareholders, $1998 \ldots \ldots \ldots \ldots \ldots \ldots \ldots \ldots$

Text Tables

1. DePfa: Capital Ratio and Asset Growth and Comparison with all Banks, 1984-1997 . . . . . . . . . . . . . . . . . . . . . . . . . . 11

2. DePfa (consolidated): Selected Assets, 1985-1997 . . . . . . . . . . . . . 12

3. DePfa (consolidated): Composition of Liabilities, 1985-1997 . . . . . . . . . . . 12

4. Comparing DePfa's and All Bank's Earnings, 1984-1997 . . . . . . . . . . . . 13

5. Fannie Mae, Growth of Equity, Assets, and MBS Relative to House Price Index 1971-1997 . . . . . . . . . . . . . . . . . . . . . . . . . . . . 20

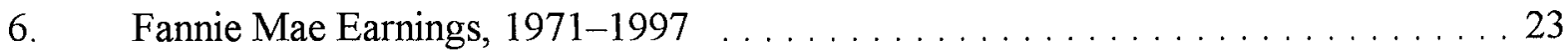




\section{INTRODUCTION}

Special purpose state banks can be described as financial institutions explicitly empowered to pursue defined policy objectives, enjoying special status within the financial sector. This status often includes implicit or explicit government guarantees and allows for a certain degree of non-market behavior. Switching ownership from the state sector to private hands changes the objective function of the bank from satisfying a complicated bureaucratic mission to the simple goal of maximizing profits.

When ownership is transferred to private hands, special privileges become unfair competitive advantages, weakening market efficiency. Optimal privatization, defined as the efficient provision of the financial service involved, implies full removal of special privileges, and with it the removal of the bank's policy function. If the special status is not terminated, privatization is complete but the bank is endowed with advantages not available to all potential competitors.

The grant of special market privileges can lead to adverse behavior and destabilization of financial markets. Alternatively, or additionally, the grant of market privileges will promote rent-seeking behavior to protect and extend the privileges. If the privileges are quantitatively substantial, then a barrier to entry is created that engenders a suboptimal market structure much like Adam Smith's reviled "royal chartered monopoly" (Smith 1965). The financial institution created through the grant of special privileges will almost certainly be subject to the too-big-to fail syndrome, shifting a substantial burden of default risks to the state.

Privatization is often motivated by general fiscal considerations, where the government is under pressure to quickly enhance revenue. Ironically, the goal of maximizing fiscal revenue may be best served by not fully removing existing privileges of the privatized bank because future expected returns from special privileges (rents) are reflected in the share price, raising revenue for the state. Despite significant literature on these problems and their often noted relevance in financial markets, surprisingly little attention is paid to them in planning many privatizations. The result has been a high degree of failure, associated with costs far in excess of privatization revenues.

This paper presents two case studies of privatization, that of Fannie Mae in the United States and DePfa Group (DePfa) in Germany. The two institutions represent examples of privatization with and without the complicating factor of a grant of special privileges. Both are major players in their markets. With assets of about US $\$ 125$ billion, DePfa is the largest mortgage bank in Europe and Fannie Mae is the largest private bond issuer with assets and mortgage backed-securities together of about US $\$ 890$ billion. 
Section 2 surveys economic policy issues involved in bank privatization. Sections 3 and 4 present case studies of DePfa and Fannie Mae respectively, focusing on legal and regulatory privileges economic performance. Section 5 contains conclusions and some lessons that may apply across a larger spectrum of financial institutions and countries.

\section{Policy Issues in Bank Privatization}

\section{A. Special Purpose State Banks and Missing Markets}

Special purpose state banks are initially formed as public policy instruments to overcome identified market failure (missing market) problems. ${ }^{2}$ Missing markets exist where a service is not offered in the market even though the cost of providing the service is less than what individuals are willing to pay. Initial start-up costs, (often called threshold costs) may preclude or delay private creation of the market. The missing market element is crucial for future privatization because it indicates that bank is commercially viable once the missing market has been established.

The mission of a state bank is to provide the designated service and at the same time to develop a market infrastructure which will eventually allow new, private entities to enter, making it a competitive market. ${ }^{3}$ The missing market rationale for state banks suggests that banks should be privatized when the missing market has been established. An important test of whether or not a given state bank is fit for privatization would be to determine the existence of private competitors in the absence of significant entry barriers. If competitors do not exist, privatization of the bank would simultaneously entail privatizing a policy function, which goes much beyond the privatization of a single institution. Under such circumstances, privatization may not be the optimal strategy.

\section{B. Potential for Market Failure}

Successful privatization means maximizing the efficient provision of the financial service involved in the economy. This requires minimizing common market failures. Market failures will be deliberately exploited by the newly privatized institution in following a different objective function than existed for the state-owned institution. The new objective

\footnotetext{
${ }^{2} \mathrm{~A}$ distinction can be made between state-owned commercial banks and special purpose state banks. In Germany, for instance, most state banks such as the Landesbanken, and savings banks are, for the most part, universal banks operating according to commercial principles and fully subject to legal and regulatory framework. By contrast, special purpose banks pursue defined policy goals such as housing, small enterprise development.

${ }^{3}$ In many transition economies, privatization of state banks is complicated because the banks often are sole providers of credit in their market segment (agriculture, housing, tourism, and trade).
} 
function maximizes profits. When this objective encounters an environment with market failures, profitability is enhanced at the expense of the efficient provision of financial service.

Therefore, the success of privatization can not be measured by the short-run profitability of the privatized firm, or the revenue generated for the state. In fact, these are to a large extent inversely related to the success of privatization. Anticipation of enhanced profitability will raise the value of the bank and increase the income to the state treasury. However, enhanced profitability usually comes at the expense of financial market efficiency. Thus, from the outset, the privatization process is troubled by both the buyers and the sellers having an incentive to perform a nonoptimal privatization.

Major areas commonly leading to market failures are market power and moral hazard arising out of the bank's political connections which may allow regulatory forbearance. There is also a principal-agent problem stemming from the public perception that the bank continues to benefit from state guarantees. Privatization might also entail information rents stemming from the banks' close ties to political insiders; and regulatory capture, stemming from a bias in regulators' perception of the (former state) banks' presumed high degree of safety. Public offerings of state banks may also entail special problems, including insider dealings and fraud.

The privatization of banks requires careful planning on the part of the state to anticipate and curb potential market failures. Most importantly, the state must determine, with some certainty that the market has indeed been established, justifying the retreat of the state. Privatization is a success when market failures have been minimized. If the institutional, legal, and regulatory environment is not in place, privatization should generally not be undertaken despite the clear commercial viability of the privatized bank.

\section{Privatization of DePfa}

The DePfa was founded in 1922 as a public sector mortgage bank. ${ }^{4}$ Its original purpose was to provide mortgage-based lending to private home-owners, especially multifamily residential homes. The bank was authorized to issue mortgage bonds to raise

funds in the capital markets. While these bonds were not guaranteed by the state, they enjoyed an indirect protection via the bank's status as state-owned entity. In 1950, its purpose was

\footnotetext{
${ }^{4}$ It was called Preussische Landespfandbriefanstalt (Prussian mortgage institution) and was incorporated as state-owned entity (oeffentlich-rechtlich). As of Jan 1, 1999, DePfa restructured its operations and took a new name, DePfa-Deutsche Pfandbriefbank AG - BauBoden, where Bau-Bodenbank is integrated. DePfa (as a holding company) covers the areas of state finance, issuing of securities, and management. National and international commercial mortgage finance and real estate holdings are shifted to Bau-Bodenbank.
} 
modified slightly to promote low income housing (social housing projects) and to promote private ownership. In 1989, it was transformed into a publicly listed company, it first offered shares on the stock exchange and was fully privatized in 1991. DePfa now has the legal status of a private mortgage bank (Box 1).

The decision to privatize DePfa and other state-owned entities was closely linked to budgetary needs of the government. However, an additional impulse to privatize came from the government's policy of more forceful implementation of the model of social market economy, by shedding state property wherever this was possible without impinging upon and hindering public policy.

By the mid-1980s, DePfa's policy function no longer played an important role. Housing finance had become a prerogative of regional governments and the original purpose of DePfa was already served sufficiently by other financial institutions, notably the local savings and cooperative banks. ${ }^{5}$ For these reasons a federally owned mortgage bank had become redundant. Privatization was facilitated by the fact that DePfa had already begun to reorient its business orientation (within the scope of its statutes) as an active participant in the market for subnational state lending. With this, DePfa's profile was already very similar to those of private mortgage institutions so that privatization promised to be a smooth one.

${ }^{5}$ Until the 1980s, these banks relied primarily on household deposits for funding, making it virtually impossible to offer long-term fixed interest housing loans. Today, these banks can obtain longer term funding through their associated institutions at the federal level (such as the Landesbanken or the DG Bank for cooperative banks). 


\section{Box 1. Steps to Privatization of DePfa}

1968 - Governmental Inquiry finds that DePfa's business is largely integrated in a competitive market.

1976 - DePfa's status as "instrument of the housing policy" and tax-exempt status are discontinued.

1979-DePfa takes over 92.5 percent of Bau- und Bodenbank AG, state-owned building society.

1983-The government announces its intention to reduce direct business engagements of the state. The intention is to privatize state assets without impinging upon public policy objectives.

1985-A comprehensive privatization program is announced which includes DePfa. Shares held by the state are reduced to a simple majority by 1987.

1986-Ministry of Finance prepares DePfa's transformation to publicly listed company.

1988-Law to transform DePfa into a publicly listed company passed; effective January 1, 1989.

1989-DePfa shareholder meeting votes on the transformation into a publicly listed company as of November 17 and book-entry into the commercial register as of year-end 1989.

1991-DePfa shares are introduced on the public stock exchange. (Initial listing price is DM 400; two years later the shares trade at DM 900).

Initially, the government held the view that in the case of mortgage banks, state ownership was justified as a counterweight to private mortgage banks, most of which were wholly owned by a small group of major private banks. The government was concerned that DePfa would be purchased by a major bank and thus fostering further concentration in banking. This concern was addressed by broadly dispersing shares at the initial public offering. As shown in Chart 1 below, DePfa's ownership has remained relatively dispersed since privatization. 


\section{Chart 1: DePfa Bank Shareholders, 1998}

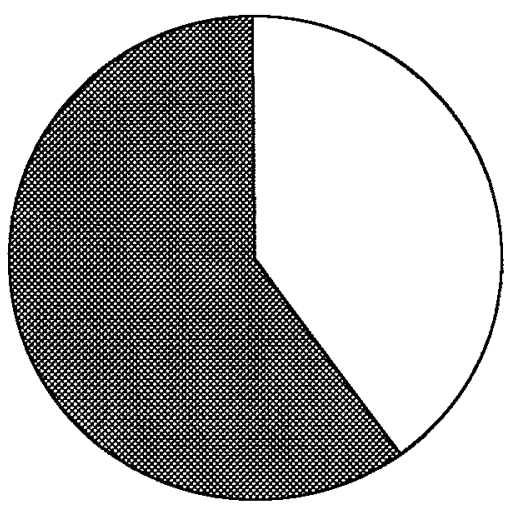

\section{$\square$ DePfa Holding 圈 Dispersed Ownership}

Major Shareholders of DePfa Holding

8.34\% Bayerische Beamten Lebensversicherung (Insurance Company)

$5.07 \%$ Bankhaus Lampe KG (Commercial Bank)

$4.90 \%$ Deutscher Ring Beteiligungsholding (Investment Fund)

Source: DePfa Annual Report 1998

\section{A. Road Map to Phasing out Special Privileges}

While DePfa's policy function had already been largely removed, the bank's special status and privileges remained. These were removed prior to privatization, in most cases grandfathering privileges on already outstanding debt subject to a ten-year limit at which point all substantial privileges were fully phased out. The following major issues arose:

\section{Abandoning the maintenance obligation of the state}

As a state-owned bank, DePfa was subject to special protection under the so-called maintenance obligation of the state (Anstaltslast). The maintenance obligation of the state, indirectly translates into a quasi-guarantee of all of its liabilities. With privatization of DePfa, the maintenance obligation was relinquished. This raised the question of whether bonds issued before privatization would cease to be subject (protected by) the maintenance obligation. 
The federal government grandfathered the preexisting quasi-state guarantee for all liabilities predating December 31, 1989, the point at which DePfa was listed in the commercial registry. This decision helped smooth the transition and maintain the level of confidence.

\section{Phasing in prudential limits applicable to private sector mortgage banks}

Public and private mortgage banks are subject to the same capital requirements. ${ }^{6}$ However, private mortgage banks are additionally subject to a liabilities to asset ratio. They must also limit bond issues to 60 times capital. Since this second limitation did not apply to DePfa prior to its privatization, DePfa's borrowings exceeded these limits by about 10 percent at the time of the planned privatization. The law governing DePfa's privatization states that DePfa must fully comply with the law ten years following the entry into the commercial register (as of 2001). The rationale was that DePfa could reasonably be expected to reduce the excess by about one percentage point per year without unduly disrupting its operations.

\section{Guarantees by DePfa}

Guarantees by state banks (including DePfa) play an important role in private mortgage banks' refinancing practices. First ranking mortgage loans can be refinanced by issuing mortgage bonds (Hypothekenpfandbriefe) ${ }^{7}$ By contrast, mortgage lending that is not first ranked (in excess of 60 percent of the mortgage lending value) can not be refinanced with mortgage bonds unless a public sector institution provides a guarantee. Such guarantees permit private mortgage banks to expand their lending without requiring additional capital.

Privatization ended DePfa's ability to offer these guarantees. Without special transition arrangements, there was uncertainty about the status of outstanding guarantees. Moreover, private mortgage banks may have been in violation of current regulations. This problem was addressed by a legal provisions specifying that outstanding DePfa guarantees would remain valid even after DePfa's state-owned status had ended. The provision of mortgage credit was not affected because DePfa was not a large supplier of such guarantees.

\section{Participations}

By law, private mortgage banks are barred from participations in other banks or enterprises. As exception to policy, it was decided that DePfa would be permitted to continue owning Bau- and Bodenbank, another building society that was formerly owned by the state.

\footnotetext{
${ }^{6}$ Gesetz ueber Pfandbriefe und verwandte Schuldverschreibungen oeffentlich-rechtlicher Kreditanstalten (ÖPG).

${ }^{7}$ First ranking (1. Rang des Grunduches) constitutes the highest priority creditor status. A mortgage loan may not exceed 60 percent of the loan value.
} 


\section{Issues concerning the status and remuneration of staff}

No special problems arose in the area of the status and remuneration of staff because DePfa (as most state-owned banks) participated in the salary policy and contracts (Tarifvertraege) of the privately owned banks. It was, therefore not necessary to develop special rules for transforming the staff's salary structure. In this respect, state banks are fully integrated in the financial market and compete for staff and management with private banks.

Similarly, in the case of the staff's pension plan, privatization of DePfa did not require substantial changes. Already in 1966, DePfa had phased out contributions for its staff to a state-owned pension fund (supplementing mandatory contributions to the federal social security system). At present, DePfa maintains its own internal supplementary pension fund. In this regard, privatization of DePfa was considerably less complicated than the privatization of the postal bank (Postbank) where employees had civil servant status which raised additional difficulties. $^{8}$

\section{Time limitations for transition arrangements}

With the exception of the participation in Deutsche Bau- und Bodenbank AG, (and remaining old debts outstanding) DePfa must, as of the year 2000, fully adhere to all laws, rules and regulations applicable to private mortgage banks. With this provision, DePfa management has limited scope to exploit any privileges which remain during the transitional period.

\section{B. Economic Performance Since Privatization}

Efficiency considerations did not drive the privatization of DePfa. Even before privatization, the institution was professionally managed and its staff had no special privileges (or job security). Moreover, the bank was self-sustaining and did not receive a capital infusion from its owners. As the following discussion of DePfa's performance shows, DePfa increasingly abandoned its original business of financing low income housing and instead entered into lending to subnational governments, both in Germany and EU-wide. With this orientation, DePfa followed the trend of other private mortgage houses.

\section{Capital and asset growth and asset quality}

As shown in Table 1, DePfa's unweighted capital to asset ratio has remained almost constant at about 1.4 percent over the ten-year period before and after privatization. Capital infusions mostly came from retained earnings. On a risk-weighted basis, core capital ratio is

\footnotetext{
${ }^{8}$ In essence, civil servants were allowed to keep their status even after privatization while any newly hired staff were offered standard private sector contracts. Thus, a dual track system was established that is phased out as civil servants retire.
} 
just over 7 percent (1995-1997), well above the minimum ratio of four percent for core capital recommended in the Basle capital accord (figures provided by DePfa).

Table 1. DePfa: Capital Ratio and Asset Growth (unconsolidated) and Comparison with All Banks, 1984-1997

\begin{tabular}{|c|c|c|c|c|c|c|}
\hline & \multirow[t]{2}{*}{ Total Equity } & \multirow[t]{2}{*}{ Total Assets } & \multirow{2}{*}{$\begin{array}{r}\text { Equity/Assets } A \\
\text { percen }\end{array}$} & \multirow{2}{*}{ Asset Growth } & \multicolumn{2}{|c|}{$\begin{array}{l}\text { Average Growth Before and } \\
\text { After Privatization }\end{array}$} \\
\hline & & & & & $\begin{array}{l}\text { DePfa } \\
\text { percent }\end{array}$ & $\begin{array}{l}\text { All Banks } \\
\text { percent }\end{array}$ \\
\hline 1984 & 839 & 61,100 & 1.37 & & & \\
\hline 1985 & 867 & 59,140 & 1.47 & -3.2 & & \\
\hline 1986 & 892 & 62,756 & 1.42 & 6.1 & & \\
\hline 1987 & 912 & 62,764 & 1.45 & 0.0 & & \\
\hline 1988 & 912 & 63,441 & 1.44 & 1.1 & & \\
\hline 1989 & 934 & 64,046 & 1.46 & 1.0 & & \\
\hline 1990 & 977 & 63,378 & 1.54 & -1.0 & 0.7 & 6.9 \\
\hline 1991 & 1,005 & 67,099 & 1.50 & 5.9 & & \\
\hline 1992 & 1,208 & 79,516 & 1.52 & 18.5 & & \\
\hline 1993 & 1,546 & 96,824 & 1.60 & 21.8 & & \\
\hline 1994 & 1,624 & 101,444 & 1.60 & 4.8 & & \\
\hline 1995 & 1,992 & 125,683 & 1.58 & 23.9 & & \\
\hline 1996 & 2,037 & 136,400 & 1.49 & 8.5 & & \\
\hline 1997 & 2,129 & 148,478 & 1.43 & 8.9 & 13.2 & 8.7 \\
\hline
\end{tabular}

Source: DePfa Annual Reports and Bundesbank Banking Statistics

DePfa's asset growth accelerated significantly after privatization from about 1 percent to about 13 percent average growth respectively for the six years before and after privatization. The increase was almost fifty percent faster than the growth of the national average for all banks. Rapid asset growth perhaps indicates that with privatization, management's objectives focus on profit maximization (and perhaps market share) rather than its former policy function. Table 2 on DePfa's asset composition shows that mortgage loans, the bank's original focus, fell from about 21 percent of total assets in 1984 to about 16 percent in 1997. At the same time, DePfa increased its exposure to subnational governments from about 50 percent of assets in 1984 and 65 percent in 1997. Loans to banks fell from a peak of almost 38 percent in 1991 to about 14 percent in 1997 . The relative decline in loans to banks may have raised profitability, as DePfa increasingly engaged in direct lending. The business orientation follows closely the profile of other private mortgage banks. 
Table 2. DePfa (consolidated): Selected Assets, 1985-1997 (in DM million and percent)

\begin{tabular}{|c|c|c|c|c|c|c|}
\hline & $\begin{array}{c}\text { Mortgage } \\
\text { Loans } \\
\text { (DM million) }\end{array}$ & $\begin{array}{c}\text { Mortgage Loans } \\
\text { as Percent of } \\
\text { Total Assets }\end{array}$ & $\begin{array}{l}\text { State Loans } \\
\text { (DM million) }\end{array}$ & $\begin{array}{c}\text { State Loans is } \\
\text { Percent of Total } \\
\text { Assets }\end{array}$ & of which: to banks & percent of assets \\
\hline 1985 & 13,900 & 21.5 & 32,600 & 50.5 & 16,500 & 25.5 \\
\hline 1986 & 14,700 & 22.5 & 35,600 & 54.4 & 21,400 & 32.7 \\
\hline 1987 & 15,100 & 22.0 & 35,900 & 52.3 & 24,200 & 35.3 \\
\hline 1988 & 15,600 & 22.4 & 37,400 & 53.8 & 23,000 & 33.1 \\
\hline 1989 & 15,900 & 22.6 & 37,400 & 53.1 & 24,300 & 34.5 \\
\hline 1990 & 16,600 & 23.5 & 36,900 & 52.3 & 24,400 & 34.6 \\
\hline 1991 & 16,100 & 21.1 & 38,400 & 50.3 & 28,600 & 37.5 \\
\hline 1992 & 20,100 & 21.8 & 45,600 & 49.4 & 33,000 & 35.8 \\
\hline 1993 & 25,700 & 23.1 & 69,400 & 62.4 & 33,300 & 29.9 \\
\hline 1994 & 28,100 & 23.3 & 76,274 & 63.2 & 29,900 & 24.8 \\
\hline 1995 & 29,200 & 19.3 & 99,000 & 65.5 & 31,200 & 20.6 \\
\hline 1996 & 31,500 & 18.3 & 113,900 & 66.2 & 30,500 & 17.7 \\
\hline 1997 & 33,300 & 16.4 & 132,400 & 65.3 & 28,600 & 14.1 \\
\hline
\end{tabular}

Source: DePfa Annual Reports

Table 3. DePfa (consolidated) Composition of Liabilities, 1985-1997 (DM million and percent)

\begin{tabular}{|c|c|c|c|c|c|c|c|}
\hline & $\begin{array}{l}\text { G ov't Bonds } \\
\text { DM million }\end{array}$ & $\begin{array}{l}\text { (Percent of } \\
\text { Liabilities) }\end{array}$ & $\begin{array}{l}\text { Mtg. Bonds } \\
\text { DM million }\end{array}$ & $\begin{array}{l}\text { (Percent of } \\
\text { Liabilities) }\end{array}$ & $\begin{array}{l}\text { Other bonds } \\
\text { DM million }\end{array}$ & $\begin{array}{l}\text { (percent of } \\
\text { Liabilities) }\end{array}$ & $\begin{array}{c}\text { Total bonds/ } \\
\text { Total Assets } \\
\text { (percent) }\end{array}$ \\
\hline 1985 & 31,900 & 49.4 & 9,600 & 14.9 & 2,300 & 3.6 & 67.8 \\
\hline 1986 & 34,000 & 52.0 & 10,100 & 15.4 & 1,700 & 2.4 & 69.9 \\
\hline 1987 & 32,200 & 46.9 & 9,600 & 14.0 & 900 & 1.3 & 62.2 \\
\hline 1988 & 31,400 & 45.1 & 10,000 & 14.4 & 100 & 0.1 & 59.7 \\
\hline 1989 & 32,900 & 46.7 & 10,200 & 14.5 & 200 & 0.3 & 61.5 \\
\hline 1990 & 33,800 & 47.9 & 9,600 & 13.6. & 200 & 0.3 & 61.8 \\
\hline 1991 & 38,200 & 50.1 & 10,000 & 13.1 & 100 & 0.1 & 63.3 \\
\hline 1992 & 49,600 & 53.7 & 9,600 & 10.4 & 700 & 0.7 & 64.9 \\
\hline 1993 & 55,400 & 49.8 & 6,200 & 7.8 & 5,800 & 5.2 & 60.6 \\
\hline 1994 & 57,000 & 47.3 & 5,800 & 7.1 & 11,300 & 9.4 & 61.4 \\
\hline 1995 & 67,500 & 44.6 & 5,900 & 5.8 & 21,600 & 14.3 & 62.8 \\
\hline 1996 & 77,700 & 45.1 & 5,000 & 4.7 & 31,100 & 18.1 & 66.1 \\
\hline 1997 & 81,100 & 40.0 & 4,600 & 3.9 & 38,400 & 18.9 & 61.2 \\
\hline
\end{tabular}


On the liability side (Table 3 ), about 40 percent are bonds issued by DePfa which are backed by state loans mentioned above. Mortgage bonds have rapidly diminished to about 4 percent of the bank's funding while other bonds issued by DePfa contribute about 19 percent of total funding in 1997 as compared with about 4 percent in 1984. In 1994, DePfa received a triple A rating for its public bonds from Moody's as well as for its mortgage bonds. This increased its international standing and reduced its funding costs relative to other mortgage banks which were either not rated or given a lower rating.

\section{Earnings}

As shown in Table 4, DePfa's net interest margin (net interest earned divided by yearend assets) has remained relatively stable at about 0.46 percent. Return on equity has fallen from a very high level of about 25 percent in 1984 to about 8 percent in 1997, although the fall reflects the build-up of capital rather than a decline in earnings. The stable earnings appear to reflect two trends. Favorable ratings after privatization permit DePfa to borrow at rates more advantageous than those of its competitors. Secondly, expansion into state financing in EU member countries appears to be profitable, replacing the previous focus on mortgage lending.

Table 4. Comparing DePfa's and Banking Sector Earnings, 1984-1997 (in percent)

\begin{tabular}{lccccc}
\hline & $\begin{array}{c}\text { Net Interest } \\
\text { Margin }{ }^{\prime}\end{array}$ & $\begin{array}{c}\text { Net Earnings' } \\
\text { Assets }\end{array}$ & $\begin{array}{c}\text { Net Earnings' } \\
\text { Equity }\end{array}$ & $\begin{array}{c}\text { Return on Equity } \\
\text { all German banks }\end{array}$ & $\begin{array}{c}\text { Return on Equity: } \\
\text { DePfa minus all Banks }\end{array}$ \\
\hline 1984 & 0.45 & 0.10 & 25.2 & 19.0 & 6.2 \\
1985 & 0.42 & 0.09 & 22.8 & 18.0 & 4.8 \\
1986 & 0.44 & 0.07 & 18.7 & 16.0 & 2.7 \\
1987 & 0.34 & 0.07 & 10.6 & 14.0 & -3.4 \\
1988 & 0.51 & 0.07 & 10.8 & 14.0 & -3.2 \\
1989 & 0.46 & 0.07 & 10.3 & 12.0 & -1.7 \\
1990 & 0.44 & 0.08 & 11.4 & 12.0 & -0.6 \\
1991 & 0.41 & 0.16 & 26.7 & 16.0 & 10.7 \\
1992 & 0.42 & 0.09 & 12.9 & 15.0 & -2.1 \\
1993 & 0.52 & 0.11 & 12.1 & 14.0 & -1.9 \\
1994 & 0.66 & 0.01 & 0.8 & 13.0 & -12.2 \\
1995 & 0.52 & 0.09 & 7.0 & 12.0 & -5.0 \\
1996 & 0.49 & 0.11 & 6.7 & 12.0 & -5.3 \\
1997 & 0.46 & 0.12 & 8.4 & 12.0 & -3.6 \\
\hline
\end{tabular}

Source: DePfa Annual Reports and Bundesbank Banking Monthly Reports

$1 /$ Total interest earned minus total interest expense/total assets.

$2 /$ Net interest earned divided by year-end assets. 


\section{DePfa: Summary and Conclusions}

DePfa was privatized after its policy function had been shed. Even prior to privatization, the bank was professionally run and subject to prudential oversight. Nonetheless, certain privileges, including a state guarantee, existed. These were phased out before and during the first ten years after privatization. The experience of DePfa highlights that significant regulatory and legal preparations may be needed to smooth the transition from a public to privately owned institution.

In the post privatization era, DePfa's growth has been significant relative to industry growth. Its changed behavior illustrates that the focus of bank management changed rapidly toward profit maximization and to enhancing market share, perhaps within the group of private mortgage banks to which DePfa now belongs. DePfa's ownership structure has remained relatively dispersed as was intended by the former owners (the federal government). However, it remains to be seen whether this will continue to be the case.

While DePfa continues to provide housing finance, low-income mortgage lending no longer constitutes an important area of its activities. Residential home financing has become primarily the domain of local savings banks (most of which are owned by the local communities) and cooperative banks.

\section{Privatization with Special Privileges of Fannie Mae}

Fannie Mae was incorporated in 1938 as a wholly owned government corporation (Title III of the National Housing Act (NHA). It was formed to provide a secondary market for federally supported residential mortgages. At first, it refinanced itself almost entirely by borrowing from the U.S. Treasury. Its business primarily consisted of purchase and resale of mortgages insured by the Federal Housing Administration (FHA) and, since 1948, mortgage loans guaranteed by the Veterans Administration (VA), to establish and maintain a secondary market for such mortgage loans. Title III was revised in 1954 and called the Federal National Mortgage Association Charter Act. ${ }^{9}$ Under the new Charter Act, the corporation became a mixed-ownership corporation which issued non-voting stock.

In 1968, the corporation was partitioned into two separate and distinct corporations. One, the Government National Mortgage Association (Ginnie Mae), became a wholly owned corporate entity of the United States within HUD. Ginnie Mae retained all of the assets and liabilities acquired and incurred under the special assistance functions and management and liquidation functions carried on by the predecessor corporation. Ginnie Mae performs an identical securitization function for a special market segment (VA and FHA loans).

${ }^{9}$ Moody's rating agency refers to the corporation as Federal National Mortgage Corporation (FNMA) while Fannie Mae is the corporate name used in government studies and by the corporation itself. 
Fannie Mae retained the assets and liabilities related to the secondary market operations. The corporation was authorized to issue its common stock to the public (Box 2). All preferred stock up till the point which was held by the Secretary of the Treasury was retired in 1968 and the entire equity interest in the corporation became, and is now, stockholder-owned.

Box 2. Fannie Mae: Privatization with Special Privileges

1938 - The National Housing Act (NHA) establishes Fannie Mae to provide a secondary market for federally supported residential mortgages.

1948 - The corporation is re-chartered as mixed ownership corporation. The chief function becomes serving as a primary source of funds by acquiring Federal Housing Administration (FHA), Veterans Administration (VA), and Federal housing mortgages through mortgage companies and institutions acting as originating agents.

1954 - The basic functions are redefined to include as: (1) management and liquidation of mortgages acquired from a variety of other state agencies; (2) overseeing special assistance programs for subsidized housing and other home programs, and (3) management of secondary market operations in which FHA and VA mortgages are to be acquired from mortgage companies and institutions.

1968 - (1) and (2) are transferred to a new agency, the Government National Mortgage Association (Ginnie Mae).

1968- Fannie Mae becomes a private corporation with a public purpose.

1970- Fannie Mae receives authority to buy and sell conventional mortgage loans in addition to mortgages underwritten by the FHA or VA. 


\section{A. Regulations and Exemptions}

Fannie Mae has the status of a government-sponsored entity (GSE) meaning that significant government regulation remained. ${ }^{10}$ For example, approval of the Secretary of the Treasury is required for Fannie Mae's issuance of its obligations. HUD is granted general regulatory power over Fannie Mae. The Secretary of HUD may require that a reasonable portion of Fannie Mae's mortgage loan purchases be related to the national goal of providing adequate housing for low-and moderate income families, but with a reasonable economic return to the corporation. The Secretary also has the authority to audit and examine the books and financial transactions of the corporation, but this authority has never been exercised.

Furthermore, the federal government represents its interests indirectly by appointing five of the eighteen-member Board of Directors. These are appointed by the President of the United States. One such member must be each of the home building, mortgage lending, and real estate industries. Any member of the Board of Directors, including a member elected by stockholders, may be removed by the President of the United States for good cause.

Fannie Mae is subject to supervision by a special oversight agency, the Office of Federal Housing Enterprise Oversight (OFHEO). OFHEO also supervises Freddie Mac, which is a financial institutions with a similar profile. OFHEO has developed a risk-based supervisory system for the two institutions and prepares annual (and continuous) on and off-site exams of their financial soundness.

\section{B. Monitoring of Fannie Mae by the Federal Government}

The government has continuously monitored this special status in a variety of ways, including numerous studies of the costs, benefits, and risks involved. For example, in 1992 legislation, the Congress mandated studies of the desirability and feasibility of repealing the federal charters of Fannie Mae and Freddie Mac (GAO 1996b).

\footnotetext{
${ }^{10}$ Other Government Sponsored Enterprises (GSEs) are: Farm Credit System Federal Home Loan Mortgage Corporation (Freddie Mac) Federal Home Loan Bank (FHLB) System Student Loan Marketing Association (Sallie Mae)
} 
Conclusions of these studies are that the full removal of market privileges would raise the cost of mortgages by about 25 basis points for "conforming" loans (no change for nonconforming loans) and that taxpayers would save about US $\$ 1.5$ billion per year in implicit insurance costs, and that there would be no significant effects on the availability of mortgage credit or the liquidity of the secondary mortgage market. Regional disparity is also not expected to develop. ${ }^{11}$

\section{Privileges}

\section{The Assumed (but Nonexistent) Government Guarantee}

The greatest privilege is the (legally unfounded) market belief that Fannie Mae is subject to a government guarantee. ${ }^{12}$ In fact, no portion of principal or interest of any of Fannie Mae's obligations or mortgage insurance is guaranteed by the Federal government. Moreover, the Charter requires that this stipulation be printed on each financial instrument. However, Fannie Mae obligations are believed by financial markets to be de facto guaranteed and priced accordingly. ${ }^{13}$

The empirical evidence based on the yields show that Fannie Mae securities consistently perform as well as or even outperform agency securities with explicit Federal guarantees. ${ }^{14}$ For example, the yields on Fannie Mae's mortgage-backed securities are as low as $5-10$ basis points above U.S. Treasuries. This is despite the fact that they carry substantial prepayment risk and are legally guaranteed only by Fannie Mae's slim capital reserves.

One argument used to explain this phenomenon is that as a major financial monopolist in an important market, Fannie Mae is too big too fail. (White 1998) This hypothesis is supported by improved performance of Fannie Mae securities from the early 1990s on, after capturing much of the business of the largely defunct savings and loan industry.

\footnotetext{
${ }^{11}$ Studies sponsored by or using financial support from Fannie Mae come to dissenting views on each of these issues. Some of these studies are also included in the above mentioned volume.

${ }^{12}$ Kane (1998) notes that rating agencies assign Fannie Mae a triple A rating because of the federal government's compelling incentives to insure its continued viability. Fitch rating agency is quoted as stating, "Although [... Fannie Mae's] obligations are not explicitly guaranteed by the U.S. government, Fitch believes that in the unlikely event of financial difficulties, the Federal government would support the company to the extent necessary to provide for full and timely payment of [...its...] mortgage-backed securities and unsecured senior debt."

${ }^{13} \mathrm{CBO}$ (1996) Hermalin and Jaffee (1996)

${ }^{14}$ Cotterman and Pierce (1996); Ambrose and Varga (1996); Hermalin and Jaffee (1996)
} 
Virtually all of the numerous studies on Fannie Mae's status as Government Sponsored Enterprise conclude that the benefits to the taxpayer are not overwhelming, especially as compared with the potential risks incurred. The arguments in favor of continuing the status quo are ambiguous or weak. However, little action has followed. This finding appears to be attributed, at least in part to Fannie Mae's successful lobbying activities and its active participation in this debate, supporting research arguing its own case. (Kane 1998).

\section{Other Privileges}

Fannie Mae enjoys a number of other privileges as well. Although these are somewhat more difficult to quantify they appear to be of less importance than the assumed government guarantee.

- Securities issued by Fannie Mae are considered "exempt securities" under laws administered by the Securities and Exchange Commission (SEC) to the same extent as securities that are obligations of, or guaranteed as to principal and interest by the United States. Registration statements with respect to the corporation's securities are not filed with the SEC. This may explain why Fannie Mae bonds are priced as a neargovernment institution.

- $\quad$ Fannie Mae has the authority to borrow up to US\$2.25 billion from the Secretary of the Treasury but has not used this facility since its transition from government control.

- $\quad$ Fannie Mae is exempt from all taxation by any state or by any county, municipality or local taxing authority except for real property taxes. However, Fannie Mae is not exempt from payment of federal corporate income taxes.

- Its securities are eligible as collateral when commercial banks and thrift institutions borrow from the Federal Reserve's discount window. They are eligible for purchase by the Federal Reserve in open market operations and eligible as collateral for public deposits including treasury tax and loan accounts

- Fannie Mae securities also have a favorable status in the portfolios of depository institutions; for example, the shorter-term securities may be used to meet the liquidity requirements of thrift institutions belonging to the Federal Home Loan Bank system, and national bank may invest and deal in these securities without limit. 


\section{E. Economic Performance of Fannie Mae}

Efficiency concerns did not play a large role in the decision to privatize Fannie Mae. The primary reasons for privatization were budget revenue considerations and the desire of the federal government to shed risks. Fannie Mae has kept its focus on providing secondary market services for "middle income" housing although the upper limit for housing finance is currently about US $\$ 227,000$ which covers approximately 90 percent of all home sales. Ironically, as described below, privatization has not led to a reduction in Federal exposure to Fannie Mae's portfolio risk, but has contributed to a large increase in the absolute size of the risk exposure.

\section{Capital and asset growth}

In terms of asset growth, Fannie Mae has expanded significantly faster than those prevailing in the industry, using the housing price index and asset growth of other commercial banks as comparators. Assets of Federally Sponsored Credit Agencies combined grew at a compound annual rate of 13.5 percent from 1970-1984. For purposes of comparison, nominal gross national product and total debt of nonfinancial sectors expanded at compound annual rates of 9.75 and 19.75 respectively over this period.

Fannie Mae's equity position (equity divided by assets plus the off balance sheet liability of mortgage-backed securities) shows cyclical developments from a high of about 3.5 percent in 1977 to a low of about 0.7 percent in 1986 and 1.4 percent in 1997 (Table 5). The question of whether this constitutes adequate levels of capitalization has been widely discussed in the literature and by the government (CBO 1996; GAO 1996).

In a 1991 study, the U.S. Treasury Department published a comparison of Fannie Mae's capitalization with other financial services firms such as credit companies, insurance companies, and securities brokers/dealers. In another study, comparisons with capital ratios of banks, savings and loans, and other major providers of mortgage credit were drawn. The figures show that Fannie Mae is significantly less well capitalized than any of these comparators. These studies are somewhat dated, but since the early 1990s, Fannie Mae's capital ratios have remained unchanged while banks have increased their capital ratios markedly (GAO 1996b, p.82).

Recently, OFHEO, Fannie Mae's supervisory authority has proposed risk-based capital rules which would force Fannie Mae to increase its capital base (OFHEO, 1998). Using 1997 balance sheet data as a basis for calculation, the proposed new capital adequacy for Fannie Mae would require an increase of about US $\$ 4$ billion. The methodology is based on historical data covering a time period during which real estate prices were rising. Performing the stress test using data including periods with falling real estate prices would probably suggest that capital should be increased above this level. Given the size of Fannie Mae's exposure, a every percentage point decline in real estate prices could lead to losses of US $\$ 5-15$ billion. 
Other studies suggest that without the GSE status, Fannie Mae's capitalization would produce a triple B or A rating. (Ambrose and Warga, 1996; Cotterman and Pierce, 1996) At that level, Fannie Mae would not have a cost advantage over private firms. To maintain the current triple A rating without the GSE status, Fannie Mae might have to increase its capitalization to a level of 6-10 percent, requiring a capital infusion of a minimum of US\$60 billion.

Table 5. Fannie Mae, Growth of Equity, Assets, and Mortgage Backed Securities (MBS) Relative to House Price Index 1971-1997 (US\$ million and percent)

\begin{tabular}{|c|c|c|c|c|c|c|c|}
\hline Year & $\begin{array}{l}\text { Equity } \\
\text { USD }\end{array}$ & $\begin{array}{l}\text { Assets } \\
\text { million }\end{array}$ & $\begin{array}{c}\text { MBS } \\
1 / \\
\text { USD mill }\end{array}$ & $\begin{array}{l}\text { Equity/ } \\
\text { Assets+MBS } \\
\text { USD million }\end{array}$ & $\begin{array}{c}\text { Growth of Assets }+ \\
\text { MBS } \\
\text { percent }\end{array}$ & $\begin{array}{l}\text { Weighted Sales } \\
\text { House Price } \\
\text { Index USA }\end{array}$ & $\begin{array}{l}\text { Fannie Mae } \\
\text { Growth Minus } \\
\text { Price Index }\end{array}$ \\
\hline 1971 & 460 & 18,591 & - & 2.47 & n.a. & n.a. & n.a. \\
\hline 1972 & 559 & 20,346 & - & 2.75 & 9.4 & n.a. & n.a. \\
\hline 1973 & 680 & 24,618 & - & 2.76 & 21.0 & n.a. & n.a. \\
\hline 1974 & 772 & 29,671 & - & 2.60 & 20.5 & n.a. & n.a. \\
\hline 1975 & 861 & 31,596 & - & 2.73 & 6.5 & n.a. & n.a. \\
\hline 1976 & 983 & 32,393 & - & 3.03 & 2.5 & 8.2 & -5.7 \\
\hline 1977 & 1,173 & 33,980 & - & 3.45 & 4.9 & 12.6 & -7.7 \\
\hline 1978 & 1,362 & 43,506 & - & 3.13 & 28.0 & 12.7 & 15.3 \\
\hline 1979 & 1,501 & 51,300 & - & 2.93 & 17.9 & 12.2 & 5.7 \\
\hline 1980 & 1,457 & 57,897 & - & 2.52 & 12.9 & 5.7 & 7.2 \\
\hline 1981 & 080 & 61,579 & 717 & 1.73 & 7.6 & 3.8 & 3.8 \\
\hline 1982 & 953 & 72,981 & 14,450 & 1.09 & 40.3 & 2.6 & 37.7 \\
\hline 1983 & 1,000 & 78,383 & 25,121 & 0.97 & 18.4 & 3.9 & 14.5 \\
\hline 1984 & 918 & 87,798 & 35,738 & 0.74 & 19.4 & 4.0 & 15.4 \\
\hline 1985 & 1,009 & 99,076 & 54,552 & 0.66 & 24.4 & 6.5 & 17.9 \\
\hline 1986 & 1,182 & 99,621 & 95,568 & 0.61 & 27.1 & 9.9 & 17.2 \\
\hline 1987 & 1,811 & 103,459 & 135,734 & 0.76 & 22.5 & 7.8 & 14.7 \\
\hline 1988 & 2,260 & 112,258 & 170,097 & 0.80 & 18.0 & 6.4 & 11.6 \\
\hline 1989 & 2,991 & 124,315 & 216,512 & 0.88 & 20.7 & 6.2 & 14.5 \\
\hline 1990 & 3,941 & 133,113 & 288,075 & 0.94 & 23.6 & 0.4 & 23.2 \\
\hline 1991 & 5,547 & 147,072 & 355,284 & 1.10 & 19.3 & 2.7 & 16.6 \\
\hline 1992 & 6,774 & 180,978 & 424,444 & 1.12 & 20.5 & 1.9 & 18.6 \\
\hline 1993 & 8,052 & 216,979 & 471,306 & 1.17 & 13.7 & 2.3 & 11.4 \\
\hline 1994 & 9,541 & 272,508 & 484,345 & 1.26 & 10.0 & 1.3 & 8.7 \\
\hline 1995 & 10,959 & 316,550 & 513,230 & 1.32 & 9.6 & 5.1 & 4.5 \\
\hline 1996 & 12,773 & 351,041 & 548,173 & 1.42 & 8.4 & 3.3 & 5.1 \\
\hline 1997 & 13,793 & 391,673 & 579,138 & 1.42 & 8.0 & 3.2 & 4.8 \\
\hline
\end{tabular}

1/ Off- balance sheet liabilities for the insurance coverage of outstanding mortgage- backed securities.

Source: OFHEO Report to Congress, 1998 
In case of major losses, Congress and the Administration would probably have to step in and make good on the implicit guarantee, as the markets apparently expect, given the acceptance and pricing of Fannie Mae's mortgage backed securities. One government source estimates that the contingent lability is about US\$ 1.3 trillion. ${ }^{15}$

\section{F. Earnings and Rent Seeking}

Fannie Mae buys individual mortgages from mortgage originators through a proprietary desktop loan evaluation package ("Desktop Underwriter"). Once the loan has been successfully processed by the originator, the mortgage is saleable to Fannie Mae. The mortgage could be reprocessed and sold elsewhere, but the expense and time of this, given the small size of the mortgage (usually between US $\$ 80,000$ and US $\$ 227,000$ ) and the highly competitive nature of the mortgage origination market would make this prohibitively costly. Fannie Mae's cost-of-funds advantage relative to others (excluding Freddy Mac) is about 40 basis points which allows Fannie Mae along with Freddy Mac together to monopolize the market for conforming mortgages.

Fannie Mae assembles the single mortgages into mortgage pools, and increases their creditworthiness through the mandatory purchase of mortgage insurance by the mortgage originator. The pooled product is auctioned off on the mortgage-backed securities market. Fannie Mae also provides insurance services by guaranteeing timely payment on its mortgage bonds.

Fannie Mae is highly profitable (Table 6) with return on equity of about 25 percent. The special privileges granted Fannie Mae have been estimated to generate about half of their profits (CBO, 1996). This calculation, however, understates the case because it does not attribute their monopoly status to these special privileges. Additionally, size makes its offerings the standard securities in their markets, giving the institution a degree of liquidity that other mortgage-backed securities do not possess (Reinebach 1998). This liquidity characteristic is of significant value to the institution (Lee 1998). Size and secondary market guarantees allow transparent valuation and complex financial engineering that could not be consistently conducted in thinner markets. Thus the assertion that Fannie Mae has become a natural monopoly has merit.

Furthermore, as befits its private status, Fannie Mae has become an avid rent seeker, using technology, vertical market control and perhaps political influence to solidify its position. All of these strategies are consistent with Fannie Mae's ownership structure, market position and financial capacity. The market failure giving rise to Fannie Mae's excess profitability is being successfully expanded by Fannie Mae as a rational, long-term

\footnotetext{
${ }^{15}$ See: Stanton, in Studies 1996. The estimates are taken from The Budget of the U.S. Government, 1996, Analytical Perspectives, p.122.
} 
maximization strategy. Fannie Mae has positioned itself as the gate keeper between two highly competitive markets, the mortgage originators and the mortgage backed securities market. Fannie Mae has adopted strategies which considerably increase competition in both of these markets, while simultaneously strengthening its position as the monopoly intermediary. It has been a highly successful strategy but one that would not have been possible without the special privileges.

Another less subtle form of rent seeking involves manipulation of the political process to limit competition (Morgenson, 1997). Given Fannie Mae's dominant market position, most significant potential competition comes from other government or GSE institutions. There are numerous reports that Fannie Mae keeps a vigilant eye on all legislation that would allow other institutions to introduce competition in its market (Muolo 1997). Recent proposals to expand the ability of the Federal Home Loan Bank System to compete with Fannie Mae have provoked a flurry of lobbying (Mayer 1997).

\section{G. Policy Options to Remove Privileges}

The most common policy option discussed for Fannie Mae is the removal of the privileges not accorded other private financial firms (CBO, 1991; Barry 1997; Hermalin and Jaffee 1996). A complication, as pointed out by White (White, 1996) and others is that this would leave the "too big to fail" implicit liability guarantee in place, at least for a transitory period until other competitors have entered the market. It has also been suggested that an explicit guarantee be made, and that Fannie Mae should pay an annual insurance premium to the Treasury (Hermalin and Jaffee, 1996).

Another reform would be renationalization. Ginnie Mae may be outperforming Fannie Mae on an efficiency basis (Fogarty, 1997). One problem with renationalization is Fannie Mae's high profitability. When sold in 1968, Fannie Mae was valued as a niche player, and not as the financial behemoth it has become. The monopoly profits are now fully priced into the stock, making a renationalization an expensive proposition. However, as the stock value is mainly the result of special privilege, paying a market price would validate Fannie Mae's rentseeking strategy, creating moral hazard. Therefore, if renationalization is chosen, a two-step process should be followed. First, Fannie Mae must pay an annual assessment for the implicit subsidy, plus, perhaps a one-time retroactive assessment. Following this, the value of Fannie Mae's shares should reflect the value of the business without capitalizing the value of their special privileges. 
Table 6. Fannie Mae, Earnings, 1971-1997

\begin{tabular}{|c|c|c|c|c|c|c|c|}
\hline \multirow[t]{2}{*}{ Year } & \multirow[t]{2}{*}{ Equity } & \multirow[t]{2}{*}{ Assets } & \multirow[t]{2}{*}{ MBS 1/ } & \multirow{2}{*}{$\begin{array}{l}\text { Net } \\
\text { Income } \\
\text { million } \\
\text { US\$ }\end{array}$} & \multirow{2}{*}{$\begin{array}{c}\text { Net Income/ } \\
\text { Assets } \\
\text { percent }\end{array}$} & \multirow{2}{*}{$\begin{array}{c}\text { Net Interest } \\
\text { Margin 1/ } \\
\text { percent }\end{array}$} & \multirow{2}{*}{$\begin{array}{c}\text { Return on } \\
\text { Average Equity } \\
\text { percent }\end{array}$} \\
\hline & & & & & & & \\
\hline 1971 & 460 & 18,591 & & 61 & 0.33 & 0.4 & 14.4 \\
\hline 1972 & 559 & 20,346 & & 96 & 0.47 & 0.84 & 18.8 \\
\hline 1973 & 680 & 24,618 & & 126 & 0.51 & 0.98 & 20.3 \\
\hline 1974 & 772 & 29,671 & & 107 & 0.36 & 0.7 & 14.7 \\
\hline 1975 & 861 & 31,596 & & 115 & 0.36 & 0.73 & 14.1 \\
\hline 1976 & 983 & 32,393 & & 127 & 0.39 & 0.82 & 13.8 \\
\hline 1977 & 1,173 & 33,980 & & 165 & 0.49 & 0.95 & 15.3 \\
\hline 1978 & 1,362 & 43,506 & & 209 & 0.48 & 0.98 & 16.5 \\
\hline 1979 & 1,501 & 51,300 & & 162 & 0.32 & 0.7 & 11.3 \\
\hline 1980 & 1,457 & 57,897 & & 14 & 0.02 & 0.04 & 0.9 \\
\hline 1981 & 1,080 & 61,579 & 717 & (206) & $(0.33)$ & -0.74 & -17.2 \\
\hline 1982 & 953 & 72,981 & 14,450 & (192) & $(0.26)$ & -0.72 & -18.9 \\
\hline 1983 & 1,000 & 78,383 & 25,121 & 49 & 0.06 & -0.01 & 5.1 \\
\hline 1984 & 918 & 87,798 & 35,738 & (71) & $(0.08)$ & -0.11 & -7.4 \\
\hline 1985 & 1,009 & 99,076 & 54,552 & (7) & $(0.01)$ & 0.15 & -0.7 \\
\hline 1986 & 1,182 & 99,621 & 95,568 & 105 & 0.11 & 0.4 & 9.5 \\
\hline 1987 & 1,811 & 103,459 & 135,734 & 376 & 0.36 & 1 & 23.5 \\
\hline 1988 & 2,260 & 112,258 & 170,097 & 507 & 0.45 & 0.89 & 25.2 \\
\hline 1989 & 2,991 & 124,315 & 216,512 & 807 & 0.65 & 1.16 & 31.1 \\
\hline 1990 & 3,941 & 133,113 & 288,075 & 1,173 & 0.88 & 1.39 & 33.7 \\
\hline 1991 & 5,547 & 147,072 & 355,284 & 1,363 & 0.93 & 1.42 & 27.7 \\
\hline 1992 & 6,774 & 180,978 & 424,444 & 1,323 & 0.73 & 1.37 & 26.5 \\
\hline 1993 & 8,052 & 216,979 & 471,306 & 1,873 & 0.86 & 1.38 & 25.3 \\
\hline 1994 & 9,541 & 272,508 & 484,345 & 2,132 & 0.78 & 1.24 & 24.3 \\
\hline 1995 & 10,959 & 316,550 & 513,230 & 2,144 & 0.68 & 1.16 & 20.9 \\
\hline 1996 & 12,773 & 351,041 & 548,173 & 2,715 & 0.77 & 1.18 & 24.1 \\
\hline 1997 & 13,793 & 391,673 & 579,138 & 3,056 & 0.78 & 1.17 & 24.6 \\
\hline
\end{tabular}

Source: OFHEO Report to Congress, 1998 


\section{H. Summary}

Efforts to correct Fannie Mae's deficiencies have been repeatedly made over the last 20 years. Apparently, Fannie Mae has sufficient political support to prevent any corrections. There is ample evidence that Fannie Mae spends large amounts to maintain political allies. As the size and profits have increased, it appears unlikely that reform is possible. The estimated cost to taxpayers was about 1.2 billion dollars per year in 1994, and this has been increasing at a compound rate of $10-15$ percent per year.

Fannie Mae is an example of privatization without removing privileges. The status as privately owned Government Sponsored Enterprise allows the institution to operate in a protected environment, reaping excess profits without fully assuming the risks. This status produces a subsidy to Fannie Mae that is captured by shareholders as a windfall profit, and is not passed on to home owners. This is problematic both because welfare theory indicates that the redistribution of resources through a subsidy is soboptimal, and because it is generally recognized as encouraging moral hazard. The discomfort with the ambiguous role of Fannie Mae is evident in governmental reports. Fannie Mae is an important example of a suboptimal privatization process.

\section{Conclusions AND Lessons from DePfa AND FANNiE MAE}

This paper traces the privatization experience of DePfa and Fannie Mae, focusing on the approach to dealing with special privileges. The choice of institutions (profitable banks operating in relatively efficient capital markets with mature regulatory and legal systems) would appear to allow conclusion about privatization under relatively favorable conditions. Certain issues that may arise in less developed financial market settings, such as the lack of suitable buyers and banks' operational inefficiency do not constitute significant stumbling blocks.

Nonetheless, a number of issues become apparent that may contain useful general lessons for policy makers. The most important lesson is that privatization should go hand in hand with a complete removal of privileges and the bank's policy function. DePfa is an example of how a road map could be developed for bank privatization after shedding all policy functions with a view of phasing out all privileges. It provides interesting practical insights into the transition arrangements that are needed to fully integrate a state bank into the general legal and regulatory framework without creating disruptions to the bank or to capital markets.

Fannie Mae is an example of a privately owned institution with special privileges. Endowed with these privileges, Fannie Mae has been able to build a quasi-monopoly. The result are efficiency loss and moral hazards associated with a too-big-to fail status. The case study also shows that once a special status has been granted, it is virtually impossible to remove it. 


\section{A. Key Lessons from the Case Studies}

- Successful privatization requires maximizing the efficient provision of the financial service involved in the economy which in turn implies minimizing market failure.

- When privatized banks maintain special privileges for more than a short transitory period, continued special oversight is needed. This is a complicated task absorbing significant additional supervisory capacities to avoid abuse.

- After privatization, the incentive structure and behavior of banks changes rapidly. The single objective of profit maximization replaces complex bureaucratic missions.

- $\quad$ Regulations and regulatory practices may not catch up quickly enough with the privatized banks' new behavior.

- $\quad$ Privatizing a bank which performs a policy function is considerably more difficult than privatizing a bank after its policy functions have been shed.

- If there are incipient market failures, these will be quickly and fully exploited by the privatized bank to realize excess profits, to build up market power and engage in rent seeking.

- Privatization is a one-time (non-reversible) event: Once the privatized bank operates with privileges from the past, it will be virtually impossible for regulators to remove these privileges. 


\section{REFERENCES}

“Aktienanalyse: DePfa-Bank," Blick durch die Wirtschaft (May 24, 1995, page 3).

Ambrose, B. and Arthur Warga, 1996 "Implications of Privatization; The Cost of Fannie Mae and Freddie Mac," in GAO $1996 b$.

Association of Public Sector Banks (Verband oeffentlicher Banken), 1995, Banken und Oeffentlicher Auftrag Berichte und Analysen No. 22, Bonn.

Barry, John S., 1997 "Why Congress Should Privatize Fannie Mae and Freddie Mac," The Real Estate Journal, Boston, (Spring).

Commission on Money and Credit, 1963, Federal Credit Programs Prenctice Hall, Englewood Cliffs, N.J.

Congressional Budget Office (CBO), 1996, Assessing the Public Costs and Benefits of Fannie Mae and Freddie Mac, (May). www.cbo.gov/reports/htm 1990, "Controlling the Risks of Government-Sponsored Enterprises. As Required by the Omnibus Budget Reconciliation Act of 1990," U.S. Government Printing Office.

Cotterman, R.F. and James E. Pearce, 1996 "Effects of Fannie Mae and Freddie Mac on Conventional Fixed-Rate Mortgage Yields" in: GAO, $1996 b$.

DePfa Annual Reports (Various issues).

"DePfa: Ein Geraeuschloser Wandel, 1996 (The Silent Transformation)," Zeitschrift fuer das Gesamte Kreditwesen No.12, pp.555-556.

Dziobek,, Claudia and John R. Garrett, 1998 "Convergence of Regulatory Systems and Regulatory Policy," Competition and Convergence in Financial Markets, ed. by Stanley W. Black and Mathias Moersch, (Amsterdam: Elsevier Press).

Dougell, Herbert E., 1970, Capital Markets and Institutions (Prentice-Hall: Englewood Cliffs, New Jersey)

Fogarty, Mark, 1997, "Government National Mortgage Association," U.S. Banker (Jan.).

General Accounting Office (GAO) 1996, "Housing Enterprises. Potential Impacts of Severing Government Sponsorship," May (GAO/GGD-96-120). 1996b, Studies on Privatizing Fannie Mae and Freddie Mac, prepared for (U.S.) GAO, HUD, Department of Treasury, and CBO, (May) (Washington: U.S. Department of Housing and Urban Development). 
Hermalin, B. And Dwight Jaffee, 1996 "The Privatization of Fannie Mae and Freddie Mac: Implications for Mortgage Industry Structure," GAO, $1996 \mathrm{~b}$.

Hermann, Christiane, 1997, "DePfa-Bank Heute ein Europaeischer Player" Boersen-Zeitung, No.168, page 11 (September 3).

Kane, Edward, 1998, "Fannie, Freddie, and their Wannabe Flubbie: Subsidy, Subsidy, Where is the Subsidy?" Unpublished conference paper.

Lee, Peter, 1998, “A Mad Rush for Liquidity,” Euromoney (June).

Mayer, Martin, 1997 “Alex Pollock, Giant Killer?,” Institutional Investor (Aug.).

Moody's Bank and Finance Manual, 1998.

Moran, Michael, 1985, "Federally Sponsored Credit Agencies" Federal Reserve Bulletin, Vol. 71 (June), pp. 373-88.

Morgenson, Gretchen, 1997, "Fall of the House of Fannie," Forbes (Oct. 6).

Muolo, Paul, 1997, "Is FHLB Program a Threat to Lenders?," U.S. Banker (July)

Office of Federal Housing Enterprise Oversight (OFHEO) 1998, Report to Congress (Washington)

Reinebach, Alan N., 1998, "Fannie Mae Sells US\$4 Billion Benchmark Notes Offering," The Investment Dealer's Digest, (Jan. 19).

Smith, Adam, 1965, An Inquiry into the Nature and Causes of the Wealth of Nations, ed. by Edwin Cannan (New York: The Modern Library), pp.595-606.

White, Lawrence J., 1996 "Competition Versus Harmonization - An Overview of International Regulation of Financial Services," International Financial Markets, ed. by Claude E. Barfield (Washington: the AEI Press). 1998, “Enter Freddie Mac and Fannie Mae," Secondary Mortgage Markets, (July). 